\title{
Autoreactive T Lymphocytes in Multiple Sclerosis Determined by Antigen-induced Secretion of Interferon- $\gamma$
}

Tomas Olsson,* Wang Wei Zhi," Bo Höjeberg,"* Vasilios Kostulas," Jiang Yu-Ping," Gudrun Anderson, ${ }^{3}$ Hans-Peter Ekre, ${ }^{5}$ and Hans Link*

${ }^{*}$ Department of Neurology, Karolinska Institutet, Huddinge University Hospital, Huddinge, Sweden; ${ }^{\ddagger}$ Center for Biotechnology, Novum, Karolinska Institutet, Huddinge, Sweden; and ${ }^{\S}$ Research and Development Immunobiology, Kabi Biopharma, Stockholm, Sweden

\begin{abstract}
Multiple sclerosis (MS) is a disease with unknown cause characterized by inflammation and demyelination in the central nervous system. Although an autoimmune pathogenesis has been suggested, there are no conclusive data on the number of $T$ cells autoreactive with myelin antigens in MS compared to controls. We showed that $T$ lymphocytes secreting interferon$\gamma$ in response to possible target autoantigens are severalfold more common among PBL mononuclear cells in patients with MS than in patients with aseptic meningitis and tension headache. On average $T$ cells reactive with myelin basic protein (MBP), two different MBP peptides, or with proteolipid protein amounted to $2.7-5.2 / 10^{5}$ PBL from MS patients. MBPreactive $T$ cells were still more frequent among mononuclear cells isolated from the cerebrospinal fluid (CSF; $185 / 10^{5}$ CSF cells). We concluded that $T$ cells reactive with myelin autoantigens are strongly increased in MS. This approach to detect them could allow definition of immunodominant $T$ cell epitopes in individual MS patients, and thereby enable further development towards specific immunotherapy. (J. Clin. Invest. 1990. 86:981-985.) Key words: autoimmunity • demyelination • cerebrospinal fluid
\end{abstract}

\section{Introduction}

An autoimmune pathogenesis for multiple sclerosis (MS) ${ }^{1}$ has been suggested due to clinico-pathological similarities with experimental allergic encephalomyelitis (EAE). Induction of EAE depends on $\mathrm{CD}^{+} \mathrm{T}$ cells that are autoreactive with myelin proteins (1). Myelin basic protein (MBP) (2) and proteolipid protein (PLP) $(3,4)$ have both been shown to be encephalitogenic. Previous data on $T$ cell reactivities to myelin

Address reprint requests to Dr. Tomas Olsson, Department of Neurology, Karolinska Institutet, Huddinge University Hospital, S-141 86 Huddinge, Stockholm, Sweden.

Received for publication 2 April 1990.

1. Abbreviations used in this paper: $\mathrm{AM}$, aseptic meningitis; $\mathrm{CSF}$, cerebrospinal fluid; EAE, experimental allergic encephalomyelitis; MBP, myelin basic protein; MS, multiple sclerosis; PLP, proteolipid protein; PPD, purified protein derivate; $\mathrm{TH}$, tension headache.

J. Clin. Invest.

(c) The American Society for Clinical Investigation, Inc.

0021-9738/90/09/0981/05 $\$ 2.00$

Volume 86, August 1990, 981-985 antigens in MS (5-15) are partly inconsistent. One reason for failures to detect such reactivities (7-9) may be that $T$ cells recognizing myelin antigens constitute a minute proportion of the circulating $T$ cells. Even in EAE, the number of MBP reactive $T$ cells were as low as $3-4 / 10^{4}$ lymphocytes when isolated at the target (16). In MS, nonselective T cell cloning with lectins shows no myelin reactivity $(7,8,10)$ but is readily demonstrable in culture conditions selecting for $\mathrm{T}$ cell reactivity against $\operatorname{MBP}(6,8,11-13,15)$. Since MBP reactive T cells also have been cloned from healthy individuals $(5,12)$ the relevance of these observations is unclear. However, selected T cell cloning does not generally allow quantitation of $\mathrm{T}$ cell responses, which may be necessary to evaluate their importance. We were able to circumvent these problems by taking advantage of the fact that $\mathrm{T}$ cells may secrete IFN- $\gamma$ in response to the presented antigen (17). By applying an immunospot assay where such cells can be counted $(18,19)$ it was possible to estimate the number of $\mathrm{T}$ cells reactive with autoantigens, in this case different myelin antigens, both in MS patients and controls. Furthermore, this particular cytokine is of potential importance as effector molecule in MS. A therapeutic trial in MS with systemic administration of IFN- $\gamma$ led to exacerbations and general immune activation (20).

Since the immune response in neuroinflammatory diseases have been shown to be compartmentalized to the target for immune attack (21-24), we examined mononuclear cells from the cerebrospinal fluid (CSF) in addition to PBL.

\section{Methods}

Patients. Specimens of CSF and peripheral blood were obtained from 39 untreated patients ( 29 females) with clinically definite MS. Their ages were 17-68 yr (mean 42). In 33 of them CSF was examined. It was considered relevant to use samples from controls with and without neuroinflammatory disease. 16 patients (nine females) had acute aseptic meningitis (AM). Their ages were $18-80 \mathrm{yr}$ (mean 43). Samples were taken between 1-8 wk after clinical onset. CSF was examined in 15 of the AM patients. 25 patients ( 20 females) had tension headache (TH). Their ages were 29-69 (mean 47). They lacked physical or laboratory signs of organic disease. CSF was accessible for examination in seven of these.

Assay for single cells secreting $I F N-\gamma$ in response to antigen. The principles for immunospot enumeration of individual secretory cells using 96-well nitrocellulose bottomed microtiter plates (MillititerHAM, Millipore Continental Water Systems, Bedford, MA) were followed $(18,19)$. Wells were coated with $100-\mu 1$ aliquots of mouse monoclonal anti-human IFN- $\gamma$ antibody (7-B6-1) (25) at $6 \mu \mathrm{g} / \mathrm{ml}$ at $4^{\circ} \mathrm{C}$ overnight, and washed with PBS, pH 7.4. PBL were prepared on Ficoll Lymphoprep (Nyegaard, Oslo, Norway) and washed three times in 
tissue culture medium consisting of Iscove's modification of Dulbecco's medium with $2 \mathrm{mM}$ L-glutamine (both from Flow Laboratories, Irvine, U.K.), and 20\% (vol/vol) fetal calf serum (Gibco Laboratories, Paisley, U.K.). Mononuclear cells from $20 \mathrm{ml}$ of CSF, sampled into siliconized glass tubes, were pelleted by centrifugation for $10 \mathrm{~min}$ at $200 \mathrm{~g}$. The cells were resuspended and washed in tissue culture medium. $200-\mu$ l aliquots of PBL $\left(10^{6} / \mathrm{ml}, 2 \times 10^{5}\right.$ cells $)$ or CSF cells $\left(5-20 \times 10^{3}\right.$ cells) were added to appropriate wells of the plates. Antigens or lectins were added in $10-\mu 1$ aliquots to a final concentration of $10 \mu \mathrm{g} / \mathrm{ml}$. This concentration of antigen gave a maximum number of spots in preliminary experiments.

To control wells for each patient the antigen was omitted. MBP (26) and PLP (27) were prepared from bovine brain. PLP was free from any MBP contamination as checked by Western blot (28) and employing a rat polyclonal antiserum against MBP. We had access to two different synthetic peptides of MBP. We arbitrarily named the peptides $P_{4}$ and $P_{6}$, and their respective amino acid sequences corresponded to 132-150 and 174-191 of mouse MBP (29). They are homologous to the human protein except for a single substitution at position 146 (Lys to Arg). These peptides were synthesized on a peptide synthetizer (model 430A; Applied Biosystems, Inc., Foster City, CA), followed by purification on HPLC employing reverse phase chromatography on a C-18 column eluted with acetonitrile gradient $(0-60 \%)$ in $0.1 \%$ triflouroacetic acid. Amino acid analysis confirmed the correct product. Purified protein derivate (PPD) (Statens Serum Institute, Copenhagen, Denmark) and PHA (Difco Laboratories, Inc., Detroit, MI) were used as positive control antigen and mitogen, respectively. Because of limited access to CSF cells, only cultures with added MBP and without any added antigen could be analyzed for cells from this compartment. After a 48-h culture at $37^{\circ} \mathrm{C}, 7 \% \mathrm{CO}_{2}$, and humid atmosphere the plates were washed with PBS. 100- $\mu$ l aliquots of a rabbit polyclonal anti-human IFN-diluted 1/500 (Interferon Sciences, New Brunswick, $\mathrm{NJ}$ ) were added. After washing, biotinylated anti-rabbit IgG-diluted 1/1000 (Vector Laboratories, Inc., Burlingame, CA) was added followed by an avidin-biotin peroxidase complex diluted 1/200 (ABC Vectastain-Elite Kit; Vector Laboratories, Inc.) for $1 \mathrm{~h}$. After peroxidase staining (24), spots which corresponded to cells that had secreted IFN- $\gamma$ were enumerated with a dissection microscope. No spots appeared in specificity control experiments in which the capture antibody was changed to an irrelevant mouse monoclonal antibody or the rabbit polyclonal antibody omitted. To calculate the number of $T$ cells responding to a particular antigen, numbers of spots in cultures with no antigen added were subtracted from the numbers of spots in the different cultures exposed to antigen.

The data are expressed as numbers of spots $/ 10^{5}$ mononuclear cells. Mann-Whitney's U-test was used for statistical evaluation.

\section{Results}

After a 48-h culture of PBL or CSF mononuclear cells and immuno-enzyme staining for secreted IFN- $\gamma$, red-brown spots appeared that were easy to count in a dissection microscope. The number of memory $T$ cells responding specifically to an antigen were estimated after subtraction of the values obtained in cultures without antigen.

$T$ cells reactive with the different myelin autoantigens were present in peripheral blood of MS patients (Table I; Fig. 1). On average, 2.7 cells among $10^{5}$ peripheral blood mononuclear cells responded to MBP. Such cells were also found in blood from approximately one third of the two control groups, but at much lower numbers. On average the number of MBP reactive cells in blood were about sevenfold more common in MS than in AM or TH. An 10-fold higher number of T cells reactive with PLP in MS as compared with the control groups were found in blood specimens (Table I). The numbers of $\mathrm{T}$ cells responding to PPD and PHA did not differ significantly between the groups of patients.

To study whether $T$ cell reactivity against certain peptides was detectable with the present methodology, and if there are any indications of occurrence of immunodominant epitopes in MS, we used two synthetic peptides, $\mathrm{P}_{4}$ (amino acid residues 132-150 according to mouse sequence, part of MBP exons 5 and 6, and encephalitogenic in guinea pig) (29), and $P_{6}$ (amino acid residues 174-191, part of MBP exons 6 and 7, and no described encephalitogenicity) (29). As shown in Table I, the group of MS patients had $\sim 10$-fold higher numbers of T cells recognizing these peptides as compared with the two control groups. In Fig. 1, antigen reactivities in individual MS patients are plotted. Most patients showed similar reactivity to the two different peptides, however, a few patients showed a preferential but not exclusive reactivity to one of the peptides. There was generally a higher response to the peptides than to native MBP.

Due to the limited numbers of CSF cells available for analysis, only MBP reactive specific memory $T$ cells could be examined (Table I; Fig. 2). Again, the number of spots obtained from culture wells with added MBP exceeding those with no added antigen were calculated from samples of individual patients. In this way, the number of MBP reactive $T$ cells were on

Table I. Numbers of Antigen or Lectin-induced Interferon- $\gamma$ Secreting Cells/105 Mononuclear Cells

\begin{tabular}{|c|c|c|c|c|c|c|c|c|}
\hline \multirow[b]{2}{*}{ Patient group } & & \multirow{2}{*}{$\frac{\begin{array}{c}\text { Cerebrospinal } \\
\text { fluid }\end{array}}{\text { MBP }}$} & \multicolumn{6}{|c|}{ Peripheral blood } \\
\hline & & & MBP & MBP-P 4 & MBP-P 6 & PLP & PHA & PPD \\
\hline \multirow[t]{3}{*}{ Multiple sclerosis } & mean $\pm S D$ & $185 \pm 320$ & $2.7 \pm 2.7$ & $5.2 \pm 9.5$ & $4.9 \pm 9.4$ & $4.7 \pm 9.4$ & $162.2 \pm 148.7$ & $20.1 \pm 27.2$ \\
\hline & $n$ & 33 & 39 & 39 & 37 & 34 & 39 & 39 \\
\hline & $P$ value & $0.001 / 0.001$ & $0.001 / 0.001$ & $0.001 / 0.001$ & $0.001 / 0.001$ & $0.001 / 0.001$ & NS & NS \\
\hline \multirow{2}{*}{ Acute aseptic meningitis } & $n$ & 15 & 16 & 16 & 16 & 13 & 16 & 16 \\
\hline & $P$ value & NS & NS & NS & NS & NS & NS & NS \\
\hline \multirow[t]{2}{*}{ Tension headache } & mean $\pm S D$ & $4.3 \pm 9.3$ & $0.3 \pm 0.6$ & $0.4 \pm 0.7$ & $0.5 \pm 0.8$ & $0.3 \pm 0.8$ & $124.7 \pm 157.9$ & $39.9 \pm 89.5$ \\
\hline & $n$ & 7 & 25 & 25 & 25 & 20 & 25 & \\
\hline
\end{tabular}

For samples of each individual patient numbers of spots from cultures with no antigen added were calculated and subtracted from the values of the different cultures exposed to antigen. The data are expressed as numbers of spots $/ 10^{5}$ mononuclear cells. Mean values ( $m$ ), standard deviations $(S D)$, and numbers of patients $(n)$ are shown. The $P$ values refer to comparisons between MS with AM/MS with TH patients. 


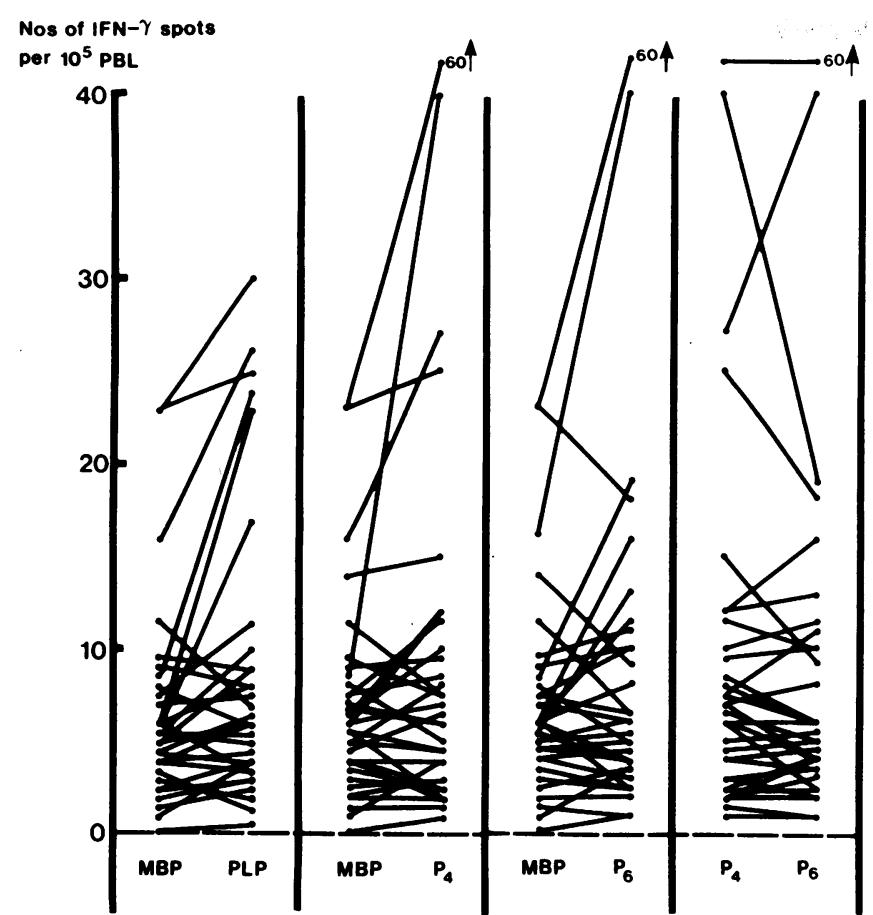

Figure 1. Numbers of spots corresponding to cells $/ 10^{5} \mathrm{PBL}$ that have secreted IFN- $\gamma$ in response to MBP, PLP, MBP-P ${ }_{4}\left(\mathrm{P}_{4}\right)$, and MBP-P 6 $\left(P_{6}\right)$. The lines connect numbers of spots obtained for each antigen in individual MS patients.

average $185 / 10^{5}$ mononuclear CSF cells and thus $\sim 30$-fold more common among MS CSF cells than among CSF cells of patients with AM or TH. Comparing frequencies of MBP reactive $T$ cells in MS blood and CSF, the frequency was $\sim 70$-fold higher in CSF.

IFN- $\gamma$ spots resulting from cell cultures with no antigen added (Table II) may represent $\mathrm{T}$ cells already activated to cytokine secretion in vivo, or memory $T$ cells responding in vitro to antigen carried with putative antigen presenting cells such as macrophages and B cells also contained in the sample. The patients with AM showed higher numbers of IFN- $\gamma$ secreting cells in blood, whereas MS patients did not differ in this

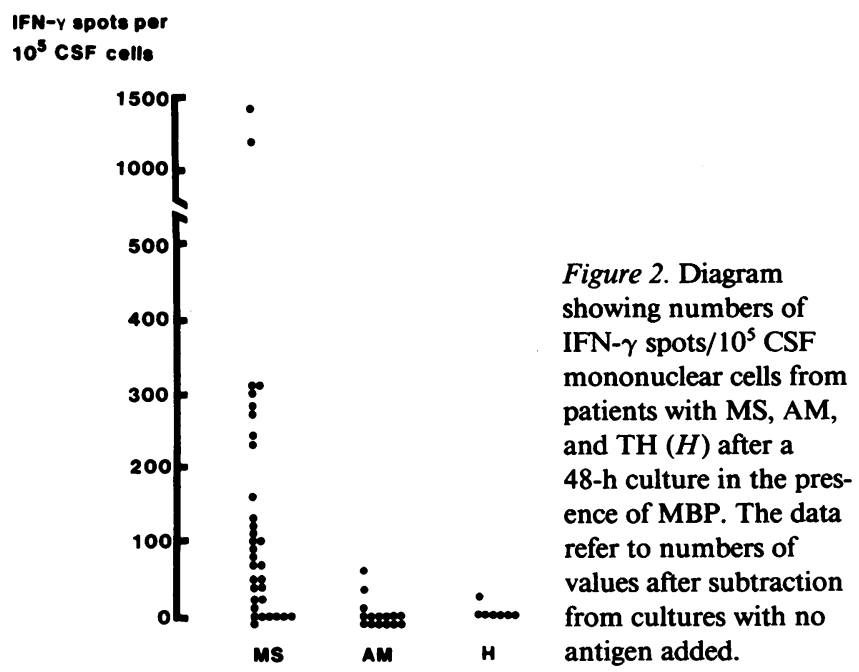

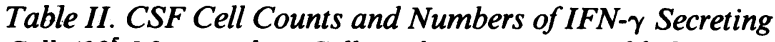
Cells $/ 10^{5}$ Mononuclear Cells with No Antigen Added

\begin{tabular}{clcccc}
\hline & & & \multicolumn{2}{c}{ IFN- $\gamma$ secreting cells } \\
\cline { 3 - 5 } Patient group & & $\begin{array}{c}\text { Mononuclear } \\
\text { cells in CSF }\end{array}$ & $\begin{array}{c}\text { Cerebrospinal } \\
\text { fluid }\end{array}$ & $\begin{array}{c}\text { Peripheral } \\
\text { blood }\end{array}$ \\
\hline \multirow{2}{*}{ Multiple sclerosis } & $\overline{\mathrm{m}} \pm \mathrm{SD}$ & $6.4 \pm 5.7$ & $384 \pm 656$ & $4.0 \pm 3.9$ \\
& $n$ & 39 & 33 & 39 \\
Acute aseptic & $P$ value & ND & $0.001 / 0.001$ & NS \\
meningitis & $\overline{\mathrm{m}} \pm \mathrm{SD}$ & $87 \pm 177$ & $99 \pm 178$ & $7.5 \pm 4.4$ \\
& $n$ & 16 & 15 & 16 \\
Tension headache & $\bar{m} \pm \mathrm{SD}$ & $1.5 \pm 0.9$ & $97 \pm 107$ & $3.0 \pm 1.7$ \\
& & $n$ & 7 & 7 & 25
\end{tabular}

Data refer to numbers of spots corresponding to IFN- $\gamma$ secreting cells $/ 10^{5}$ mononuclear cells, after $48 \mathrm{~h}$ culture of cells with no added antigen or lectin.

respect from headache patients. In CSF, however, MS patients had a marked increase in numbers of these cells, while patients with AM did not differ from those with headache (Table II). In view of an $\sim 60$-fold higher CSF mononuclear cell count in AM compared with headache patients, it can be concluded that $\mathrm{AM}$ patients have a prominent increase in IFN- $\gamma$ secreting cells in CSF. It is also interesting how patients with headache devoid of organic CNS disease signs, showed some cells that produced IFN- $\gamma$ (Table II).

\section{Discussion}

This study shows that the number of circulating $T$ cells reactive with MBP is increased in MS patients as compared with patients with AM and TH. The other important putative autoantigen in MS is PLP due to its experimental encephalitogenicity $(3,4)$. No significant $T$ cell reactivity in MS with this antigen has previously been found $(9,10)$. We now show an $\sim$ 10-fold higher number of T cells reactive with PLP in MS as compared with the control groups. These differences were not due to a generally increased capacity to produce IFN- $\gamma$ in response to antigen or lectin in MS, since the numbers of $T$ cells responding to PPD and PHA did not differ significantly between the groups of patients. The PPD response is compatible with a $T$ cell memory towards BCG, employed as vaccine in Sweden in the age groups examined. The PHA response represents a polyclonal $\mathrm{T}$ cell activation that is known to promote IFN- $\gamma$ production (19).

During antigen processing the native protein is cleaved into short peptides that $\mathrm{CD}^{+}$cells recognize when presented on MHC class II molecules (30). The $\mathrm{CD}^{+} \mathrm{T}$ cells appear to preferentially respond to peptides that bind with high affinity to the MHC class II (31). This may be the reason for the differences observed in encephalitogenicity of various MBP peptides in different animal strains. For example, the encephalitogenic peptide in Lewis rats comprises amino acid residues 68-88 of MBP (32), strain 13 guinea pigs residues 114-122 (33), and SJL/J mice residues 87-101 (34) and PL/J, residues 1-11 (35). In the genetically heterogenous population of MS patients, such immunodominant epitopes (if present) may be 
expected to differ between individuals. If such immunodominant and putatively pathogenetic peptides could be defined for each individual MS patient, specific immunotherapy could be tried as has been done successfully in EAE (36-39). With the two arbitrarily chosen peptides used here, a few patients showed a preferential but not exclusive reactivity to one of the peptides. There was a generally higher response to the peptides than to native MBP. The reason for this is unclear. Thus, individual MS patients respond to different nervous tissue proteins, and even to different peptides within the same protein. This indicates the presence of different MBP reactive $\mathrm{T}$ cell clones. On the other hand, only a minor fraction of possible peptides that can be immunodominant has been examined. We currently employ the present methodology to examine $T$ cell reactivities towards a multitude of different peptides of MBP and PLP.

In organ specific experimental autoimmune diseases such as EAE, there are indications of an enrichment of the target directed immune response to the afflicted organ (23). In MS, we recently showed elevated numbers of plasma cells producing autoantibodies against myelin antigens in CSF, but not in blood (24). Such a sequestration of the immune response to target may also occur for MBP-reactive $\mathrm{T}$ cells in MS since such cells were $\sim 70$-fold more common among CSF cells than PBL. This could either be due to selective recruitment of MBP-reactive $T$ cells to the CSF compartment or to a local clonal expansion.

Autoreactive $\mathrm{T}$ cells in MS may represent a primary cause of disease or may be the consequence of inflammatory CNS damage. The latter possibility may be valid at least partly since we have observed autoreactive $\mathrm{T}$ cells in acute cerebrovascular diseases using the same antigens and methodology (data not shown). However, this finding does not rule out a pathogenetic role of autoreactive T cells in MS. In genetically predisposed individuals, persistence of such cells at high numbers may contribute to immune-mediated tissue damage.

IFN- $\gamma$ has a special interest as an effector molecule in MS. It has previously been unsettled whether its production in MS is defective, unchanged, or increased (40). IFN- $\gamma$ is a potent immunoregulatory cytokine. Major effects include enhancement and induction of class I and II MHC gene expression (41), activation of macrophages $(42,43)$, and induction of molecules involved in $\mathrm{T}$ cell homing (44). Cytokines such as IFN- $\gamma$ usually act locally, and their production in vivo is poorly reflected in body fluids such as serum or CSF. As in this study, these problems can partly be circumvented by isolating inflammatory cells and monitoring their IFN- $\gamma$ production in vitro after short-term culture. If our data with cell cultures with no antigen added represent $T$ cells activated to IFN- $\gamma$ secretion in vivo, patients with MS have a marked increase in intrathecal IFN production. The antigen specificity of these in vivo activated $T$ cells remains unknown. The occurrence of some CSF cells that produced IFN- $\gamma$ also in patients with headache lacking organic CNS disease, is compatible with the hypothesis that systemically activated $T$ cells normally pass the bloodbrain barrier possibly to ensure immune surveillance of the brain (45).

In conclusion, $\mathrm{T}$ cells autoreactive with different myelin components are elevated in peripheral blood and strongly enriched in CSF of patients with MS. A future use of a broad spectrum of peptide antigens to detect autoreactive $T$ cells may allow definition of immunodominant epitopes that are candi- dates for specific immunotherapy in individual patients. We also expect that the single cell assay may be useful for definition of target antigens in other human diseases in which autoimmune mechanisms are suspected to operate.

\section{Acknowledgments}

This study was supported in part by grants from the Swedish Medical Research Committee (No. 7488).

\section{References}

1. Ben-Nun, A., H. Wekerle, and I. Cohen. 1981. The rapid isolation of clonable antigen specific lines capable of mediating autoimmune encephalomyelitis. Eur. J. Immunol. 11:195-199.

2. Kies, M. W., and E. C. Alvord, Jr. 1959. Allergic Encephalomyelitis. Charles C. Thomas, Publisher, Springfield, IL. 293-299.

3. Waksman, B. H., H. Porter, M. D. Lees, R. D. Adams, and J. Folch. 1954. A study of the chemical nature of components of bovine white matter effective in producing allergic encephalomyelitis in the rabbit. J. Exp. Med. 100:451-471.

4. Satoh, J., K. Sakai, M. Endoh, F. Koike, T. Kunishita, T. Namikawa, T. Yamamura, and T. Tabira. 1987. Experimental allergic encephalomyelitis mediated by murine encephalitogenic $\mathrm{T}$ cell lines specific for myelin proteolipid apoprotein. J. Immunol. 138:179-184.

5. Burns, J., A. Rosenzweig, B. Zweiman, and R. P. Lisak. 1983. Isolation of myelin basic protein-reactive $\mathrm{T}$-cell lines from normal human blood. Cell. Immunol. 81:435-440.

6. Richert, J. R., D. E. McFarlin, J. W. Rose, H. F. McFarland, and J. I. Greenstein. 1983. Expansion of antigen-specific T cells from cerebrospinal fluid of patients with multiple sclerosis. J. Neuroimmunol. 5:317-324

7. Fleischer, B., P. Marquardt, and P. Poser. 1984. Phenotypic markers and functional characteristics of $T$ lymphocyte clones from cerebrospinal fluid in multiple sclerosis. J. Neuroimmunol. 7:151-162.

8. Hafler, D. A., M. Buchsbaum, D. Johnson, and H. L. Weiner. 1985. Phenotypic and functional analysis of $T$ cells cloned directly from the blood and cerebrospinal fluid of patients with multiple sclerosis. Ann. Neurol. 18:451-458.

9. Johnson, D., D. A. Hafler, R. J. Fallis, M. B. Lees, R. O. Brady, R. H. Quarles, and H. L. Weiner. 1986. Cell-mediated immunity to myelin-associated glycoprotein, proteolipid protein and myelin basic protein in multiple sclerosis. J. Neuroimmunol. 13:99-108.

10. Hafler, D. A., D. S. Benjamin, J. Burks, and H. L. Weiner. 1987. Myelin basic protein and proteolipid protein reactivity of brainand cerebrospinal fluid-derived $\mathrm{T}$ cell clones in multiple sclerosis and postinfectious encephalomyelitis. J. Immunol. 139:66-72.

11. Richert, J. R., C. A. Reuben-Burnside, G. E. Deibler, and M. W. Kies. 1988. Peptide specificities of myelin basic protein-reactive human T-cell clones. Neurology. 38:739-742.

12. Tournier-Lasserve, E., G. A. Hashim, and M. A. Bach. 1988. Human $\mathrm{T}$-cell response to myelin basic protein in multiple sclerosis patients and healthy subjects. $J$. Neurosci. Res. 19:146-156.

13. Weber, W. E. J., and W. Buurman. 1988. Myelin basic protein-specific CD4+ cytolytic T-lymphocyte clones isolated from multiple sclerosis patients. Hum. Immunol. 22:97-109.

14. Baxevanis, C. N., G. J. Reclos, C. Servis, E. Anastasopoulos, P. Arsenis, Katsiyiannis, N. Matikas, J. D. Lambris, and M. Papamichail. 1989. Peptides of myelin basic protein stimulate $T$ lymphocytes from patients with multiple sclerosis. J. Neuroimmunol. 22:23-30.

15. Chou, Y. K., R. Vainiene, D. Whitham, C. H.-J. Bourdette, C. G. Hashim, H. Offner, and A. A. Vandenbark. 1989. Response of human $\mathrm{T}$ lymphocyte lines to myelin basic protein: association of dominant epitopes with HLA class II restriction molecules. J. Neurosci. Research. 23:207-216.

16. Cohen, J. A., D. M. Essayan, B. Zweiman, and R. P. Lisak. 1987. Limiting dilution analysis of antigen-reactive lymphocytes iso- 
lated from the central nervous system of Lewis rats with experimental allergic encephalomyelitis. Cell. Immunol. 108:203-216.

17. Hecht, T. T., D. L. Longo, and L. A. Matis. 1983. The relationship between immune interferon production and proliferation in antigen-specific, MHC-restricted T cell lines and clones. J. Immunol. 131:1049-1055.

18. Czerkinsky, C., G. Andersson, H.-P. Ekre, L.-Å. Nilsson, L. Klareskog, and Ö. Ouchterlony. 1988. Reverse ELI-SPOT assay for clonal analysis of cytokine production. Enumeration of gamma-interferon-secreting cells. J. Immunol. Methods. 110:29-36.

19. Kabilan, L., G. Andersson, F. Lolli, H.-P. Ekre, T. Olsson, and M. Troye-Blomberg. 1990. Detection of intracellular expression- and secretion of IFN- $\gamma$ at the single cell level after tetanus toxoid in vitro activation of human T cells. Eur. J. Immunol. In press.

20. Panitch, H. S., R. L. Hirsch, J. Schindler, and K. P. Johnson. 1987. Treatment of multiple sclerosis with gamma-interferon: exacerbations associated with activation of the immune system. Neurology. 37:1097-1102.

21. Baig, S., T. Olsson, and H. Link. 1989. Predominance of Borrelia burgdorferi-specific B cells in cerebrospinal fluid in neuroborreliosis. Lancet. ii:71-74.

22. Kabat, E. A., D. H. Moore, and H. Landow. 1942. An electrophoretic study of the protein component in cerebrospinal fluid and their relationship to the serum proteins. J. Clin. Invest. 21:571-577.

23. Olsson, T., A. Henriksson, and H. Link. 1985. In vitro synthesis of immunoglobulins and autoantibodies by lymphocytes from various body compartments during chronic relapsing experimental allergic encephalomyelitis. J. Neuroimmunol. 9:293-305.

24. Olsson, T., S. Baig, B. Höjeberg, and H. Link. 1990. Anti-myelin basic protein and anti-myelin antibody producing cells in multiple sclerosis. Ann. Neurol. 27:132-136.

25. Andersson, G., H-P Ekre, G. Alm, and P. Perlmann. 1989 Monoclonal antibody two-site ELISA for human IFN- $\gamma$. Adaption for determinations in human serum or plasma. J. Immunol. Methods 125:89-96.

26. Deibler, G. E., R. E. Martensson, and M. V. Kies. 1972. Large scale preparation of myelin basic protein from central nervous tissue of several mammalian species. Prep. Biochem. 2:139-165.

27. Lees, M. B. 1982. Proteolipids. Scand. J. Immunol. 15:147169.

28. Towbin, H., T. Staehlin, and J. Gordon. 1979. Electrophoretic transfer of proteins from polyacrylamide gels to nitrocellulose sheets: procedure and some applications. Proc. Natl. Acad. Sci. USA. 76:4350-4354.

29. de Ferra, F., H. Engh, L. Hudson, J. Kamholz, C. Puckett, S. Mollneaux, and R. A. Lazzarini. 1985. Alternative splicing accounts for the four forms of myelin basic protein. Cell. 43:721-727.

30. Unahue, E. R., and P. M. Allen. 1987. The basis for the immunoregulatory role of macrophages and other accessory cells. Science (Wash. DC). 136:551.

31. Buus, S., A. Sette, S. M. Colon, C. Miles, and H. M. Grey. 1987. The relation between major histocompatibility complex (MHC) restriction and the capacity of Ia to bind immunogenic peptides. Science (Wash. DC). 235:1353-1358.

32. Vandenbark, A. A., H. Offner, T. Reshef, R. Fritz, C-H. Jen
Chou, and I. R. Cohen. 1985. Specificity of T-lymphocyte lines for peptides of myelin basic protein. J. Immunol. 135:229-233.

33. Ben-Nun, A., H. Otmy, and I. R. Cohen. 1981. Genetic control of autoimmune encephalomyelitis and recognition of the critical nonapeptide moiety of myelin basic protein in guinea pigs are exerted through interaction of lymphocyte and macrophages. Eur. J. Immunol. 11:311-316.

34. Sakai, K., S. S. Zamwil, D. J. Mitchell, M. Lim, J. B. Rothbard, and L. Steinman. 1988. Characterization of a major encephalitogenic T-cell epitope in SJL/J mice with synthetic oligopeptides of myelin basic protein. J. Neuroimmunol. 19:21-32.

35. Zamvil, S. S., D. J. Mitchell, A. C. Moore, A. J. Schwarz, W. Stiefel, P. A. Nelson, J. B. Rothbard, and L. Steinman. 1987. T-cell specificity for class II(I-A) and the encephalitogenic N-terminal epitope of the autoantigen myelin basic protein. 1987. J. Immunol. 139:1075-1079.

36. Lider, O., T. Reshef, E. Beraud, A. Ben-Nun, and I. R. Cohen. 1988. Anti-idiotypic network induced by $T$ cells vaccination against experimental autoimmune encephalomyelitis. Science (Wash. DC). 239:181-183.

37. Howell, M. D., S. T. Winters, T. Olee, H. C. Powell, D. J. Carlo, and S. W. Brostoff. 1989. Vaccination against experimental allergic encephalomyelitis with $\mathrm{T}$ cell receptor peptides. Science (Wash. DC). 246:668.

38. Vandenbark, A., G. Hashim, and H. Offner. 1989. Immunization with a synthetic $\mathrm{T}$-cell receptor $\mathrm{V}$-region peptide protects against experimental autoimmune encephalomyelitis. Nature (Lond.). 341:541.

39. Wraith, D. C., D. E. Smilek, D. J. Mitchell, L. Steinman, and H. O. McDevitt. 1989. Antigen recognition in autoimmune encephalomyelitis and the potential for peptide-mediated immunotherapy. Cell. 59:247-255.

40. Billiau, A., H. Carton, H. Heremans, and K. Heierwegh. 1987. A role for the interferon system in multiple sclerosis. In Cellular and Humoral Immunological Components of Cerebrospinal Fluid in MS. A. Lowenthal and S. Raus, editors. Plenum Publishing Corp. New York. 419-428.

41. Skoskiewicz, M. J., R. B. Colvin, E. E. Schneeberger, and P. S Russell. 1985. Widespread and selective induction of major histocompatibility complex-determined antigens in vivo by $\gamma$-interferon. $J$. Exp. Med. 162:1645-1664.

42. Adams, D. O., and T. A. Hamilton. 1987. Molecular transductional mechanisms by which IFN gamma and other signals regulate macrophage development. Immunol. Rev. 97:5-27.

43. Goldberg, M., L. S. Belkowski, and B. R. Bloom. 1990. Regulation of macrophage function by interferon- $\gamma$. Somatic cell genetic approaches in murine macrophage cell lines to mechanisms of growth inhibition, the oxidase burst, and expression of the chronic ganulomatous disease gene. J. Clin. Invest. 85:563-569.

44. Duijvestijn, A. M., A. B. Schreiber, and E. C. Butcher. 1986. Interferon-gamma regulates an antigen specific for endothelial cells involved in lymphocyte traffic. Proc. Natl. Acad. Sci. USA. 83:91149118

45. Wekerle, H., C. Linington, H. Lassman, and R. Meyermann. 1986. Cellular immune reactivity within the CNS. Trends Neurosci. 9:271-277. 